\title{
Practice of Cross-infection Control for Dental Impression in Commercial Dental Laboratory
}

\author{
Dr. Dilesh Pradhan, ${ }^{1}$ Dr. Lajana Shrestha, ${ }^{1}$ Dr. Junu Lohani, ${ }^{1}$ Dr. Jivesh Munankarmi ${ }^{1}$ \\ ${ }^{1}$ Department of Prosthodontics, Kathmandu Medical College, Duwakot, Bhaktapur, Nepal.
}

\begin{abstract}
Introduction: Dental professionals are at the risk of exposure to wide varieties of microorganisms from blood and saliva of patients to airborne infection from microbial-laden aerosols and spatter created during laboratory procedures. Dental laboratories are usually disregarded when planning effective infection and exposure control measures. Contaminated impression may act as a vehicle for transmission of infectious agents.
\end{abstract}

Objective: The objective of this study was to assess the practice of dental technicians towards infection control and to evaluate practice of the same for dental impressions in commercial dental laboratories.

Methods: Self-administered standard questionnaire was distributed to 35 dental laboratories and 31 participated in the study. The answers were collected by the investigators themselves. The data obtained were computed and analysed to find the results.

Results: Among all dental laboratories, 21 (67.75\%) ensure dental impression is disinfected in clinic. 18 (58.06\%) wear gloves when receiving clinical items and 27 (87.10\%) transfer the items in separate sealed plastic bag. Of all, 25 (80.64\%) of the dental laboratories have separate receiving area for dental impression and 23 (74.19\%) of the dental technicians continue to wear protective barriers (gloves, mask and apron) during work. In total, 29 (93.55\%) of the dental laboratories confirmed, none of their technicians has ever attended any course or training in cross-infection control.

Conclusion: The practice of cross-infection control for dental impression in commercial dental laboratories is acceptable. There should be proper guidelines from the regulating body on the protocol of infection control and laboratory waste disposal.

Keywords: Cross-infection control; dental impression; dental laboratory.

\section{INTRODUCTION}

Dental professionals, whether working with patients in clinics or in dental laboratories, are always at risk of exposure to a wide variety of microorganisms from blood and saliva of patients and also to airborne infections from microbial-laden aerosols and spatter created during laboratory procedures. ${ }^{1}$ Sixty-seven percent of the impressions, dentures, crowns and wax occlusal rims showed microorganisms of various pathogenicity which included Enterobacter cloacae, Escherichia coli, Klebsiella oxytoca, and many others. ${ }^{2}$ Contaminated impression and prosthesis may act as vehicles for transmission of infectious agents, to and from the dental

\section{Correspondence:}

Dr. Dilesh Pradhan

Department of Prosthodontics, Kathmandu Medical College, Duwakot, Bhaktapur, Nepal.

email:pradhan235@yahoo.com

\section{Citation}

Pradhan D, Shrestha L, Lohani J, Munankarmi J. Practice of crossinfection control for dental impression in commercial dental laboratory. J Nepal Soc Perio Oral Implantol. 2019;3(6):58-61. clinics and the laboratories. Literature suggests various preventive measures to control cross-infection: vaccination against susceptible infections, use of effective barriers (gloves, mask, eye glasses, and preventive clothing), use of chemical agents for disinfection of dental impressions both in clinics and dental laboratories, and proper management of clinical and laboratory waste. ${ }^{3,4}$ Although the practice of infection control should be strictly implemented in dental clinics, dental laboratories are usually disregarded when planning effective infection and exposure control measures. The objective of this study was to assess the practice of dental technicians toward infection control and to evaluate the practice the same for dental impression in commercial dental laboratories.

\section{METHODS}

This is a descriptive cross-sectional questionnaire-based study. Ethical approval for the study was granted by Institutional Review Committee of Kathmandu Medical College on 20th May 2019. Convenience (non-probability) sampling method was used for data collection. Sample size 
was calculated using following formula: Sample size $(\mathrm{n})=$ $4 \mathrm{pq} / \mathrm{e} 2$

Where, $\mathrm{p}=$ Prevalence from previous study; $\mathrm{q}=100-\mathrm{p}$; and $\mathrm{e}=$ margin of error. Sample size calculation has been done taking into consideration, the involvement of study participants in research from study done by Sedky ${ }^{5}$ which was found to be $92 \%$ for dental technicians.

Putting this value into formula, (for dental technicians)

$p=92 \% ; q=100-92=8 \% ; e=10 \%$ of 92

Actual sample size $(\mathrm{n})=\frac{4 \times 92 \times 8}{}$

$\left[\frac{10}{1000} \times 92\right]^{2}$

$=2944 / 84.64$

$=34.78$
Rounding off, the sample size for dental technicians was taken as 35 .

Commercial dental laboratories receiving dental impressions from dental clinics were included in the study. Selfadministered standard questionnaire with reference to similar survey $^{5}$ was prepared and distributed to 35 dental laboratories in Kathmandu. The purpose and nature of the study were clearly mentioned in the consent form both in English and Nepali language. Out of 35 dental laboratories, 31 participated in the study. The answers were collected by the investigators themselves. The data obtained were computed in Microsoft Excel (2016) and analysed to find the results.

\section{RESULTS}

The questionnaire and the responses are illustrated in Table 1.

Table 1: Questionnaire and response, $\mathbf{n}(\%)$.

\begin{tabular}{|c|c|c|}
\hline Question & Response & Frequency \\
\hline \multirow{4}{*}{ Number of impressions received in a week } & $<20$ & $6(19.36)$ \\
\hline & $20-30$ & $6(19.36)$ \\
\hline & $31-50$ & $2(6.45)$ \\
\hline & $>50$ & $17(54.83)$ \\
\hline \multirow{2}{*}{$\begin{array}{l}\text { Do you ensure clinical items are disinfected } \\
\text { in clinic before receiving them }\end{array}$} & Yes & $21(67.75)$ \\
\hline & No & $10(32.25)$ \\
\hline \multirow{2}{*}{$\begin{array}{l}\text { Do you wear gloves when receiving clinical } \\
\text { items }\end{array}$} & Yes & $13(41.94)$ \\
\hline & No & $18(58.06)$ \\
\hline \multirow{3}{*}{$\begin{array}{l}\text { How to you carry impression from dental } \\
\text { clinic to laboratory }\end{array}$} & Separate plastic bag with seal & $27(87.1)$ \\
\hline & Separate plastic bag without seal & $2(6.45)$ \\
\hline & Carry all impression from different clinic in same bag & $2(6.45)$ \\
\hline \multirow{2}{*}{$\begin{array}{l}\text { Does your laboratory separate receiving area } \\
\text { for dental impression }\end{array}$} & Yes & $25(80.64)$ \\
\hline & No & $6(19.36)$ \\
\hline \multirow{2}{*}{$\begin{array}{l}\text { Do you wear gloves, mask and apron during } \\
\text { work }\end{array}$} & Yes & $23(74.19)$ \\
\hline & No & $8(25.81)$ \\
\hline \multirow{3}{*}{$\begin{array}{l}\text { Do you disinfect or wash dental impression } \\
\text { after receiving in laboratory }\end{array}$} & No & $7(22.59)$ \\
\hline & Wash and Spray with disinfectant & $2(6.45)$ \\
\hline & Wash and dry with cotton & $22(70.96)$ \\
\hline \multirow{2}{*}{$\begin{array}{l}\text { Have any of your employee attended any } \\
\text { course for cross-infection control? }\end{array}$} & Yes & $2(6.45)$ \\
\hline & No & $29(93.55)$ \\
\hline \multirow{3}{*}{$\begin{array}{l}\text { Do you know what diseases can you } \\
\text { contaminate if you don't follow proper } \\
\text { infection control protocol? }\end{array}$} & No & $7(22.59)$ \\
\hline & Yes (but cannot specify) & $9(29.03)$ \\
\hline & Yes (can specify - Tuberculosis, Hepatitis , HIV) & $15(48.38)$ \\
\hline \multirow{3}{*}{$\begin{array}{l}\text { Do you use proper disposable system for } \\
\text { laboratory waste? }\end{array}$} & Yes & $18(58.06)$ \\
\hline & No & $11(35.49)$ \\
\hline & No response & $2(6.45)$ \\
\hline
\end{tabular}




\section{DISCUSSION}

Cross-infection is defined as the transmission of infectious agents between patients and staff within a clinical environment. ${ }^{6}$ It can also take place between the patient and dental technicians by transferring contaminated items from dental clinics to dental laboratories and vice versa. Impression material exposed to infected saliva and blood may act as a source of transmission of microorganisms, which may lead to the spread of transmissible diseases such as acquired immunodeficiency syndrome (AIDS), hepatitis, herpes, tuberculosis and many others. ${ }^{3,7}$ According to the study done in Nepal, ${ }^{8}$ nearly 260,000 individuals are chronically infected with Hepatitis B Virus (HBV) and a majority of them are unaware of their infection.

Universal precautions guidelines advocated the avoidance of direct physical contact with "all moist and potentially infectious body substances," even if blood is not visible. ${ }^{9}$ The British Dental Association, ${ }^{10}$ Australian Dental Association, ${ }^{11}$ and American Dental Association ${ }^{12}$ have published guidelines that describe the infection control procedures, dental practitioners and their clinical support staff are expected to follow in a dental practice. Nepal also has published "Infectious Disease Control Guideline"13 but less has been mentioned about the preventive measures in dental practice. As per international guidelines followed by many countries, ${ }^{10,-12,14}$ dental impression should be disinfected with proper disinfecting chemicals following manufacturer instructions, with the labels attached before it leaves the dental clinic.

The result of the present study showed most of the dental laboratory receive more than 50 impressions in a week (54.83\%). Majority of the laboratory technician ensured that the dental impression they are receiving from the clinic is disinfected (67.75\%). They wear gloves while receiving clinical items (58.06\%) and carry dental impression in a separate plastic bag with a seal (87.1\%). After receiving the dental impression, for which most of them have a separate receiving area/unit (80.64\%), only two of the 31 participating labs disinfect the impression after washing in running water, 22 (70.96\%) labs only wash the impression and seven labs never wash or disinfect the impression. Repeated disinfection and selection of wrong disinfectants for any particular dental impression may have an adverse effect on the dimensional stability and surface details of the impression. ${ }^{7}$ So it is essential to have adequate knowledge and proper communication between the clinic and dental laboratory in this regard. ${ }^{10}$ Some labs mentioned the use of Dettol soap and water for disinfection.
Almost all (93.55\%) of the participating labs mentioned their employees had never attended any course for infection control. When asked about types of diseases they can contaminate if they don't follow proper infection control protocol, we found that most of them were aware of the infectious diseases like Tuberculosis, Hepatitis, and HIV and therefore were found to using protective barriers like gloves, mask, and apron during work (74.19\%). This is a positive finding when compared to a similar type of study, where the investigators reported the poor compliance of dental technicians in using protective barriers. ${ }^{14}$

Proper disposal of laboratory waste is a vital factor in infection control. Impression materials amount to $30 \%$ of the total solid waste generated in dental practice..$^{15}$ Eighteen dental labs said they use a proper disposal system for laboratory waste. When asked about the disposal method they follow for impression material, none was found to follow the proper guidelines. ${ }^{15}$ This shows there is confusion among technicians regarding the disposal of dental laboratory waste.

Nepal Medical Council has recently introduced requirement of Continuing Professional Development (CPD) point for medical and well as dental professionals which includes infection prevention and control as mandatory verifiable CPD point to be accumulated in the given time period. ${ }^{16}$ To the knowledge of the author, there is no evidence of any guidelines to be regulating and updating the dental laboratory personals or any curriculum to produce efficient manpower in the respective field.

The major limitation of this study is a significant risk of false-positive feedback and limited sample size.

\section{CONCLUSION}

Within the limitation of this study, the authors can conclude that the practice of cross-infection control for dental impression in the commercial dental laboratory is at acceptable level. However, it is recommended that the concerned authorities (regulating bodies) set guidelines and protocols for proper infection control and laboratory waste disposal.

\section{ACKNOWLEDGEMENTS}

We would like to acknowledge Associate Professor Dr. Siddhartha Dixit and Associate Professor Dr. Punam Basnet Dixit for their continuous support, Dr. Roshna Lamichhane for assisting us in data collection and all dental laboratories who took part in this study.

Conflict of Interest: None. 


\section{REFERENCES}

1. Molinari JA. Infection Control in the Dental Laboratory. In: Cottone's Practical Infection Control in Dentistry. 3rd ed. Baltimore, Md.: Lippincott William \& Wilkins, 2010; p. 246-60.

2. Powell GL, Runnells RD, Saxon BA, Whisenant BK. The presence and identification of organisms transmitted to dental laboratories. J Prosthet Dent. 1990;64(2):235-7.

3. Infection control recommendations for the dental office and the dental laboratory. J Am Dent Assoc. 1996;127(5):672-80.

4. Blair FM, Wassell RW. A survey of the methods of disinfection of dental impressions used in dental hospitals in the United Kingdom. Br Dent J. 1996;180(10):369-75.

5. Sedky NA. Evaluation of practice of cross infection control for dental impressions among laboratory technicians and prosthodontists in KSA. Int J Infect Control. 2014;10(3):1-12.

6. Mutlu S, Porter SR, Scully C. Cross-infection control in dentistry. Istanbul, Turkey: Erofset; 1996.

7. Hemalatha R, Ganapathy D. Disinfection of dental impression- A current overview. J Pharm Sci Res. 2016;8(7):661-4.

8. Shrestha A. Viral Hepatitis in Nepal: Past, Present, and Future. Euroasian J Hepato-Gastroenterology. 2016; 6(1):59-61.

9. Broussard IM, Kahwaji CI. Universal Precautions [internet]. Updated 20. Treasure Island (FL): Stat Pearls Publishing. Jan 2020. Available from: https://www.ncbi.nlm.nih.gov/books/NBK470223/

10. British Dental Association. Health Technical Memorandum 01-05: Decontamination in Primary Care Dental Practices. [internet]. London - Department of Health; 2013. Available from: https://assets.publishing.service.gov.uk/government/uploads/system/uploads/ attachment_data/file/170689/HTM_01-05_2013.pdf

11. Australian Dental Association. In: Guidelines for infection Control. 3rd ed [internet]. Sydney: ADA Inc, 2015. Available from: https://www.ada.org.au/Dental-Professionals/Publications/Infection-Control/Guidelines-for-Infection-Control/1ADA GuidelinesforInfectionControl_3.aspx

12. Kohn WG, Collins AS, Cleveland JL, Harte JA, Eklund KJ, Malvitz DM; Centers for Disease Control and Prevention (CDC). MMWR Recomm Rep. 2003 Dec 19;52(RR-17):1-61.

13. Ministry of Health and Population, Government of Nepal. Infectious Disease Control Guideline. In: Epidemiology and Disease Control Division [internet]. Kathmandu: Department of Health Services; 2016. Available from: http://www.edcd.gov.np/resources/download/ infectious-disease-control-guideline

14. Al-Mortadi N, Al-Khatib A, Alzoubi KH, Khabour OF. Disinfection of dental impressions: Knowledge and practice among dental technicians. Clin Cosmet Investig Dent. 2019; 11: 103-8.

15. Haralur SB, Al-Qahtani AS, Al-Qarni MM, Al-Homrany RM, Aboalkhair AE, Madalakote SS. The Dental Solid Waste Management in Different Categories of Dental Laboratories in Abha City, Saudi Arabia. Open Dent J. 2015;9:449-54.

16. Nepal Medical Council (NMC). Continuing Professional Development of NMC [internet]. Institute of Medicine, Kathmandu: NMC - CPD Committee; 2010. Available from: https://cpdnmc.org.np/ 